\title{
Fərdi məlumat subyektlərinin hüquqlarının təhlili
}

\author{
Günel Vəliyeva \\ Bakı Dövlət Universiteti, Bak1, Azərbaycan \\ gn1030507@gmail.com
}

\begin{abstract}
Xülasə- Şəxsə məxsus, onu müəyyənləşdirməyə imkan verən məlumatların qorunması həm fərdi məlumatların mühafizəsi, həm də şəxsi və ailə həyatına hörmət hüququnun bir hissəsidir. Fərdi məlumat subyektləri üçün qanunvericiliklə təminat verilməli hüquqlar onların fərdi molumatlarının toplanması, emalı və istifadəsi prosesində məlumatların mühafizəsinə təsir imkanlarını gücləndirir. İnternet mühitində fərqli sahələrdə müxtəlif platformalarda məlumatların yığılması və paylanılması, üçüncü tərəflər üçün əlçatanlığı şəxslərin öz hüquqlarını həyata keçirməsi üçün fərdi məlumat subyektlərinin aktiv iştirakını və prosesə nəzarətini tələb edir. Bu da fərdi məlumat subyektləri üçün fərdi məlumatların mühafizəsi və şəxsi və ailə həyatına hörmət hüququ ilə bağlı qanunvericilikdə nəzərdə tutulmuş təminatların effektivliyindən asılıdır. Fərdi molumat subyektlərinin qanunvericilikdə nəzərdə tutulan hüquqları özündə həm fərdi mlumatların mühafizəsi, həm də insan hüquqları çərçivəsində şəxsi və ailə həyatı hüququ ilə bağlı təminatları əks etdirərək bütövlükdə qiymətləndirilə bilər.
\end{abstract}

Açar sözlor- fordi molumat, fordi molumat subyektlori, fordi molumat subyektlorinin hüquqlart

\section{GİRIŞ}

İnsan hüquqları ilə bağlı aktual məsələlərdən biri fərdi məlumatların hüquqi müdafiəsinin təmin edilməsidir. Problem onunla əlaqəlidir ki, informasiya emalının müəyyən avtomatlaşdırılmış platformalarda və ya İnternet məkanında həyata keçirilməsi və istifadəçilərin İnternetdən istifadəsi ilə əlaqədar şəxsi müəyyənləşdirməyə imkan verən fərdi məlumatlar müxtəlif formalarda kənara çıxır və ya üçüncü şəxslər üçün əlçatan ola bilir. Bu halda fərdi məlumatların aid olduğu şəxs tərəfindən ona nəzarət edilməsi mürəkkəbləşir və ya mümkün olmur.

Məlumat toplayan, emal edən və istifadə edənlərə qarşı qanunvericiliyin tələblərindən başqa, fərdi məlumatların mühafizəsində fərdi məlumat subyektlərinin hüquqlarının müəyyən edilməsi, qanunvericiliklə onlara verilən təminatların effektivliyi həlledici amil kimi çıxış edir. Buna görə də, konkret mübahisəli halları həll edərkən hüquq tətbiq edən tərəfindən fərdi məlumatların mühafizəsi və ona qarşı duran qanuni maraqlar arasında əlaqə qiymətləndirilməli və qanunvericiliklə gözlənilən ümumi maraqlar aydınlaşdırılmalıdır.

\section{II. "FORDİ MOLUMATLAR" ANLAYIŞI}

"Fərdi məlumatlar haqqında" Azərbaycan Respublikasının Qanununa [1] əsasən fərdi məlumatlar dedikdə "şəxsin kimliyini birbaşa və ya dolayısı ilə müəyyənləşdirməyə imkan verən istənilən məlumat" başa düşülür.
Fərdi məlumatlara şəxslərə verilən eyniləşdirmə nömrələri, e-poçt, şəxsin tanınmasına şərait yaradan onun fiziki, əqli, psixoloji, iqtisadi, sosial və mədəni xüsusiyyətlərini aydınlaşdıran məlumatlar aiddir. "Fərdi məlumatlar haqqında" Azərbaycan Respublikasının Qanununun 2-ci maddəsinə əsasən "xüsusi kateqoriyalı fərdi məlumatlar" anlayışı "fiziki şəxsin irqi və ya milli mənsubiyyətinə, ailə həyatına, dini etiqadına və əqidəsinə, səhhətinə və ya məhkumluğuna aid olan məlumatlar"dırlar. Müqayisə üçün Avropa Birliyinin Məlumatların Mühafizəsi haqqında Direktivinə (EU Data Protection Directive (Regulation (EU) 2016/679)) əsasən fərdi məlumat eyniləşdirilən və ya eyniləşdirilə bilinən canlı şəxslə bağlı istənilən məlumatdır. Burada fərdi məlumatların əhatə dairəsi açıq buraxılır, istənilən məlumat şəxsin kimliyini müəyyənləşdirməyə imkan verirsə, fərdi məlumat hesab olunur.

Qeyd edilməlidir ki, fərdi məlumatların hüquqi mühafizəsinin vacibliyi təhsil, səhiyyə, sosial, əmək və ayr1ayrı sahələr üzrə fərdin özünü realizəsi və hüquqlarının həyata keçirilməsi prosesində mərkəzləşdirilmiş və ya mərkəzləşdirilməmiş məlumat bazalarına daxil edilən fərdi məlumatlar üzrə avtomatlaşdırılmış proseslərlə əlaqədar və bu məlumatların üçüncü tərəflər üçün açıqlığına görə tələb olunur.

Eyni zamanda fərdi məlumatların mühafizəsinin onlayn ticarət və istehlakçı hüquqları ilə əlaqəsi İnternet mühitində ticarət platformalarının inkişafı ilə bağlı olaraq genişlənməkdədir. $\mathrm{Bu}$ mənada həmin platformalarda tələb olunan və istifadəçilər tərəfindən təqdim edilən fərdi məlumatların dairəsi və həmin məlumatların qorunması və düzgünlüyünün təmin edilməsi üçün nəzarətin səmərəliliyi şəxslərin istehlakçı kimi hüquqlarının qorunması ilə bərabər onların şəxsi hüquq və azadlıqlarının da qorunmasını şərtləndirir. Bank, ticarət, maliyyə, sığorta və digər xidmətlər göstərən şirkətlərə təqdim edilən fərdi məlumatların mühafizəsi həm bu məlumatları toplayanlar üçün, həm də istifadəçilər üçün vacib amildir. Belə ki, bu məlumatların hər hansı formada kənara sızdırılması subyektlər üçün nüfuzun aşağı düşməsi, həmçinin məlumatların aid olduğu şəxslərin hüquqlarının pozulması ilə nəticələnə bilər. Ona görə də, hər iki tərəf fərdi məlumatların mühafizəsində maraqlıdırlar.

Fərdi məlumatlar anlayışı əsas insan hüquq və azadlıqları çərçivəsində şəxsilik (privacy) hüququ ilə s1x əlaqəlidir. Şəxsilik hüququ geniş mənada şəxsin həyatına hər hansı müdaxilənin olmasını istisna edərək şəxsi və ailə həyatına hörmət hüququnun elementidir. "Fərdi məlumatların hüquqi mühafizəsi” anlayışının əsasında insan hüquqları sistemində şəxsin fundamental hüquqlarından biri "şəxsi və ailə həyatına hörmət hüququ" hüququ dayanır. "Şəxsi və ailə həyatına hörmət hüququ" İnsan hüquqları və əsas azadlıqları haqqında 


\section{"Informasiya tohlükəsizliyinin aktual multidissiplinar elmi-praktiki problemlori” V respublika konfransı, 29 noyabr 2019-cu il}

Avropa Konvensiyasının [2] 8-ci maddəsində nəzərdə tutulmuşdur. Konvensiyanın 8-ci maddəsi üzrə Avropa İnsan Hüquqları Məhkəməsinin təcrübəsində də qeyd edilir ki, fərdi məlumatların mühafizəsi fərdin şəxsi və ailə həyatına hörmət hüququndan istifadə etməsi üçün fundamental əhəmiyyətə malikdir [7, s.11]. "Şəxsi və ailə həyatına hörmət hüququ" və "fərdi məlumatların qorunması hüququ" arasında müəyyən məzmun fərqi qəbul olunduqları sahələrlə əlaqədardır. Belə ki, şəxs barədə bütün növ məlumatlar fərdi məlumatlara aid edilir. Lakin bütün məlumatlar şəxsi və ailə həyatına hörmət hüququnun əhatə dairəsinə daxil deyil. Buna görə də, fərdi məlumatların qorunması həm şəxsin əsas insan hüquq və azadlıqlarının təmin olunmasında, həmçinin bununla əlaqəli digər subyektlərin hüquqlarının qorunmasında əhəmiyyətli rol oynayır.

Beləliklə, fərdi məlumatlar ümumi olaraq iki istiqamətdə qiymətləndirilə bilər. Birinci mövqe fərdi məlumatlara şəxsi və ailə həyatına hörmət hüququnun tərkibində şəxsilik hüququ (right to privacy) istiqamətində yanaşmanı ifadə edir. İkinci mövqe isə müxtəlif platformalarda yayılma dairəsindən asılı olaraq fərdi məlumatlara fərdi məlumatların mühafizəsi (right to the protection of personal data) istiqamətində yanaşmanı ifadə edir. Hər iki mövqeni ümumiləşdirərək qeyd etmək lazımdır ki, fərdi məlumatların müdafiəsi fundamental insan hüquqlarından biridir.

\section{FORDİ MӘLUMAT SUBYEKTLORINININ HÜQUQLARI}

"Fərdi molumatlar haqqinda" Azərbaycan Respublikası Qanununun 2.1.2-ci maddəsinə əsasən "barəsində fərdi məlumatlar toplanılan, işlənilən və mühafizə edilən, kimliyi müəyyənləşdirilmiş və ya müəyyənləşdirilən fiziki şəxs" fərdi məlumatların subyektləridir. Qanunun 7-ci maddəsi fərdi məlumat subyektinin hüquqlarını müəyyənləşdirir. Fərdi məlumat subyektlərinin hüquqlarını müəyyən kriteriyalar əsasında qruplaşdırmaq olar. Subyektlərin 7-ci maddə əsasında hüquqlarını ümumiləşdirərək aşağıdakı ümumi qruplara bölmək olar:

- Şəxsin özü ilə bağlı fərdi məlumatlara çatımlılıq hüququ;

- Şəxsin özü haqqinda toplanmış məlumatların toplanılması, işlənilməsi və üçüncü şəxslərə ötürülməsi prosesində iştirak hüququ;

- Şəxsin özü barədə toplanılmış və ya işlənilmiş məlumatların silinməsi hüququ;

- Fərdi məlumatların mühafizəsinin təmin edilməsi hüququ.

Fərdi məlumatların mühafizəsinin təmin olunması həmin məlumatların toplandığı informasiya sistemlərinə qarşı bir sıra hüquqi tələblərin olması və onların yerinə yetirilməsini tələb edir. Məsələn, müvafiq uyğunluq sertifikatının mövcudluğu və ekspertiza barədə informasiya sistemlərinə tələblər subyektlərin hüquqlarının təmin olunmasına yönəlmişdir.

Fərdi məlumatların toplanılması, işlənilməsi və mühafizəsi prosesində həmin məlumatların qorunmasının insanın əsas hüququ kimi qiymətləndirilərək şəxsi və ailə həyatına hörmət hüququ ilə əlaqəli nəzərdən keçirilməsi vacibdir. Lakin fərdi məlumatların mühafizəsi yalnız bunu ehtiva etmir. İctimai maraq olan elə məsələlər ola bilər ki, fərdi məlumatların mühafizəsindən daha əhəmiyyətli ola bilər. Bununla belə, fərdi məlumatın xüsusiyyəti, xüsusi kateqoriyalı olub-olmaması da hüquqi əhəmiyyətlidir. Hər bir halda qanunvericilikdə nəzərdə tutulmuş maraqlar balanslaşdırılmalıdır. $\mathrm{Bu}$ mövqenin təcrübədə təmin edilməsi üçün hüquq tətbiqetmədə konkret işə baxılarkən sahələrarası (hüquq sahələri) əlaqədə qanuni maraqlar müəyyənləşdirilməlidir. $\mathrm{Bu}$ mənada fərdi məlumatların mühafizəsi fundamental hüquq olsa da, mütləq hüquq kimi çıxış etmir. Belə ki, fərdi məlumatların müdafiəsi hüququ bu və ya digər dərəcədə şəxsi və ailə həyatı hüququ, fikir, vicdan və din azadlıqları, məlumat və ifadə azadlıqları, ədalətli məhkəmə araşdırması hüququ və digər sosial və mədəni hüquqlarla kompleks təşkil edir.

Nümunə üçün Avropa Әdalət Məhkəməsinin təcrübəsində baxılmış Volker und Markus Schecke GbR (C-92/09) and Hartmut Eifert (C-93/09) v Land Hessen [5] işində ərizəçilər özləri barədə fərdi məlumatların Kənd təsərrüfatı və Qida üzrə Almaniya Federal İdarəsinin vebsaytında yerləşdirilməsindən şikayət etmiş̧i. Onlar barədə məlumatlar saytda Avropa Kənd Təsərrüfatı Təminatı Fondu və Kənd yerlərinin İnkişafı üçün Avropa Kənd Təsərrüfatı Fondunun benefisiarları olduqları üçün benefisiarlar barədə məlumatlar (benefisiarların adları və onlara verilmiş məbləğ) kimi yerləşdirilmişdi. Məhkəmə fərdi məlumatların qorunması və şəffaflıq öhdəliklərini qarşılaşdıraraq saytın üçüncü şəxslərə açıq olduğu üçün əlçatan olması ilə əlaqədar fərdi məlumatların qorunmasına müdaxilə olduğunu, lakin bu müdaxilənin (müdaxilənin qanunvericilikdə müəyyənləşməsi, hüquqlara hörmət, şəffaflıq və proporsionallıq şərtləri əsasında) ümumi maraq prinsipinin məqsədlərinə uyğunluğunu müəyyənləşdirmişdi [7].

Qeyd edilənlər əsasında demək olar ki, fərdi məlumatların mühafizəsi qanunvericiliyinin konkret məsələlərdə mövqeyinin dəqiqləşdirilməsinə ehtiyac vardır. Müqayisə üçün Avropa Birliyinin Məlumatların Mühafizəsi haqqında Direktivində (EU Data Protection Directive (Regulation (EU) 2016/679, Maddə 12-23) məlumat subyektinin hüquqları müəyyən qruplara ayrılaraq (şəffaflıq və modallıq, informasiya və şəxsi məlumatlara çatımlılıq, düzəliş və silinmə, etiraz etmək hüququ və avtomatlaşdırılmış individual qərar qəbul etmə, və məhdudiyyətlər) bir sira konkret hüquqi məsələləri tənzimləyir və aydın mövqe müəyyənləşdirir. Məsələn, məlumatlara çatımlılıqla bağlı hüquqlar, informasiyanın toplanması, emalı prosesində şəffaflıq və subyektlər üçün aydınlıq, unudulmaq hüququ, özü ilə bağlı məlumatların silinməsi hüququ, etiraz etmək hüququ, subyektin özündən birbaşa və ya digər şəxsdən məlumatlar toplanılarkən fərdi məlumat subyektlərinə verilməli olan məlumatlar və s. kimi həmin qruplara daxil olan hüquq və öhdəliklər konkret müəyyənləşdirilir. $\mathrm{Bu}$ da fərdi məlumat subyektlərinin hüquqlarının qorunmasında müasir çağırışlara cavab verir.

\section{FORDI MOLUMAT SUBYEKTLORININ HÜQUQLARININ TəMIN EDILMӘSININ ÜSUL Və VASITӘLӘRI}

Azərbaycan Respublikasının qanunvericiliyində fərdi məlumatların qorunmasının təmin olunması üsulları ümumi olaraq müəyyənləşdirilir, bununla belə, bəzi məsələlərə yenidən baxılması və qiymətləndirilməsi effektiv fərdi məlumatların mühafizə sisteminin formalaşması üçün vacibdir. Məsələn, məlumatların nəzarətində olduğu şəxslərin fərdi məlumat subyektlərinə qarşı öhdəlikləri ilə bağlı Qanunun 10cu maddəsində mülkiyyətçinin və operatorun vəzifələri 


\section{“Informasiya tohlükosizliyinin aktual multidissiplinar elmi-praktiki problemlori” V respublika konfransı, 29 noyabr 2019-cu il}

müəyyənləşdirilir. Lakin bu öhdəliklər ümumi xarakterlidir və toplanmış məlumatların qorunmasının təmin edilməsi ilə bağlıdır. Nümunə üçün Avropa Birliyi təcrübəsində [3] fərdi məlumatların nəzarəti altırnda olduğu idarəçiləri fərdi məlumat subyektlərinə qarşı vəzifələri konkret müəyyən olunur. Bu da idarəçi ilə bərabər fərdi məlumat subyektinə onun haqqinda toplanmış məlumata nəzarət etmək imkanı yaradır. Məsələn, Direktivin 13-cü maddəsinə əsasən fərdi məlumat subyektinin özündən məlumatlar toplanılarkən ona idarəçinin və ya onun nümayəndəsinin, məlumatların mühafizəsi ilə məsul şəxsin əlaqə ünvanlarını vermək, şəxsi məlumatların işlənməsinin hüquqi əsasları, molumatların toplanmasına razılığın verilməsi, razılığın geri götürülmüəsi, müddət, şikayətlərin verilməsi qaydaları və s. ilə bağl1 məlumatlar verilməlidir. Direktivin 14-cü maddəsi isə fərdi məlumatların fərdi məlumat subyektindən birbaşa alınmadığı hallarda fordi məlumat subyektinə təqdim edilməli olan məlumatları müəyyənləşdirir. Belə bir hüquqi tənzimlənmə subyekt üçün qanunvericiliklə nəzərdə tutulmuş hüquqlarının həyata keçirilməsi üçün konkret vasitələr və üsulları təmin edir. Fordi məlumat subyektlərinin molumatlara çatımlılıq, məlumatların dəyişdirilməsi və silinməsi, məlumatların işlənməsinin məhdudlaşdırılması, məlumatların ötürülməsi, etiraz etmək hüquqları onlara özləri barədə toplanmış məlumatlara nəzarət etmək imkanını yaradır.

Avtomatlaşdırılmış emal nəticəsində verilən qərarlar, yəni müəyyən sayda məlumatların avtomatik emalı nəticəsində əldə edilən avtomatik qərarların hüquqi effekti barədə müxtəlif müzakirələr mövcuddur. Fərdi məlumatlarla bağlı qeyd edilməlidir ki, məlumat subyektlərinin yalnız avtomatlaşdırılmış emala əsasən verilmiş qərarların subyekti olmamaları hüququnun qanunvercilikdə təsbit edilməsi vacibdir. Belə ki, hazırda İnternet əsrində, süni intellektin sürətlə qərarqəbul etmədə tətbiqi, avtomatik qərarların (sadəcə informasiyanın emalı nəticəsində texnoloji sistemin verdiyi və insan tərəfindən qiymətləndirilməmiş qərarlar) insanlara təsir imkanları böyükdür (burada həm mənfi, həm də müsbət təsir ola bilər) və həm də şəxs üzərində hüquqi nəticə yarada bilər. Ona görə də, bu məsələlərin həlli üçün şərtlər qanunvericiliklə tənzimlənməlidir.

Milli qanunvericilikdə fərdi məlumatların məhv edilməsi ilə bağlı bir neçə müddəa nəzərdə tutulub. Bu şəxs barədə fərdi məlumatların informasiya sistemlərindən silinməsini ehtiva edir. "Unudulmaq hüququ" (right to be forgotten) fərdi məlumatların qorunması və şəxsi və ailə həyatına hörmət hüququ ilə əlaqəli İnsan hüquqlarında yer alır. Azərbaycan Respublikasının qanunvericiliyində bu barədə bəzi məsələlər tənzimlənir, lakin onun konkretloşdirilməsi məlumat subyektlərinin hüquqlarının müdafiəsi üçün vacibdir. Belə ki, məhv edilmə bir neçə halda subyektin özünün istəyi ilə, məlumatın nəzərdə tutulmuş saxlanma müddəti başa çatdıqda və ya daşıyıcının məhvi və s. baş verə bilər. Unudulmaq hüququ isə subyektin özünün tələbi ilə qanunvericiliklə müəyyən əsaslarla onun barədə məlumatların silinməsini müəyyən edir.

Beləliklə, məlumatların şəxsin istəyi ilə silinməsinin əsaslarının qanunvericilikdə müəyyənləşdirilməsi bu sahədə tənzimləmənin effektivliyinə təsir edə bilər.

\section{NӘTİCӘ}

Fərdi məlumatlar 1) fundamental insan hüquqlar1; və 2) fərdi məlumatların mühafizəsi - yəni bir-biri ilə sıx bağlı olsa da, tam üst-üstə düşməyən iki fərqli çərçivədə nəzərdən keçirilir. Bununla belə, şəxsi və ailə həyatına hörmət hüququnun tərkib hissəsi kimi şəxsilik fərdi məlumatların mühafizəsinin əsasında durur. Fərdi məlumatların mühafizəsi qanunvericiliyində məlumat subyektlərinin hüquqları ilə bağlı müddəalara yenidən baxılmasına ehtiyac vardır.

İnternet mühitində və süni intellektin inkişaf etdiyi dövrdə məlumatların mühafizəsi və mühafizənin digər hüquq sahələri və qanuna əsasən gözlənilən maraqların təmin olunması ilə qarşılıqlı əlaqədə qiymətləndirilməsi zəruridir. Buna görə də, fərdi molumatların toplanmasının uyğunluq, maraqların balanslaşdırılması və ictimai maraq prinsipləri əsasında digər əsas insan hüquqlarının müdafiəsi ilə uyğunlaşdırılması prinsip kimi müəyyənləşdirilməlidir. Avtomatlaşdırılmış qərarların insanın şəxsiyyətinə və ona məxsus məlumatların mühafizəsinə təsiri də subyektlərin hüquqlarının qorunmasında nəzərə alınmalıdır.

Təhsil, sosial, iqtisadi, əmək, idarəçilik, səhiyyə, biznes və digər sahələrdə mərkəzləşdirilmiş və ya mərkəzləşdirilməmiş məlumat bazalarının və ya platformaların aktiv şəkildə tətbiqi fərdi məlumatların mühafizəsinə həssas yanaşılmanı tələb edir.

\section{İSTINADLAR}

[1] Fərdi məlumatlar haqqında Azərbaycan Respublikasının Qanunu, 11 may 2010-cu il, № 998-IIIQ. http://e-qanun.az/framework/19675

[2] Convention for the Protection of Human Rights and Fundamental Freedoms https://www.echr.coe.int/Documents/Convention_ENG.pdf

[3] EU General Data Protection Regulation.https://gdpr-info.eu/

[4] G. González Fuster and H. Hijmans The EU rights to privacy and personal data protection:20 years in 10 questions. 2019, 13 p. https://brusselsprivacyhub.eu/events/20190513.Working_Paper_Gonza $\%$ CC\%81lez_Fuster_Hijmans.pdf

[5] Volker und Markus Schecke GbR (C-92/09) and Hartmut Eifert (C93/09) v Land Hessen. Judgment of the Court (Grand Chamber) of 9 November 2010. https://eur-lex.europa.eu/legalcontent/EN/TXT/?uri=CELEX\%3A62009CJ0092

[6] Protection of personal data. Factsheet. Court of Justice of the European Union, December 2017. https://curia.europa.eu/jcms/upload/docs/application/pdf/201810/fiche_thematique_-_donnees_personnelles_-_en.pdf

[7] European Court of Human Rights Factsheet - Personal data protection. 2019. https://www.echr.coe.int/Documents/FS_Data_ENG.pdf.

\section{ANALYSIS OF THE RIGHTS OF PERSONAL DATA SUBJECTS}

Gunel Valiyeva

Baku State University, Baku, Azerbaijan

Abstract - Protection of personal data belonging to the person and providing opportunity to identify the person is part of the protection of personal data and right to respect to private and family life. Rights to be guaranteed in the legislation for the personal data subjects strengthens choices of them to influence data protection due to gathering, processing and use of them. Gathering of information and distribution in various fields on various platforms and, accessability of personal data for third parties in the Internet environment claims active participation of personal data subjects and their control on the process. And this depends on the effectiveness of the guarantees provided in the legislation for personal data subjects in respect to personal data protection and right to private and family life. İn this perspective rights of personal data subjects that needs to be provided in the legislation might be evaluated wholly reflecting both guarantees for personal data protection, and right to private and family life.

Keywords - personal data, personal data subjects, rights of personal data subjects 